\title{
Diversity of species of the genus Bolbitius (Bolbitiaceae, Agaricales) collected on dung from Punjab, India
}

\author{
Amandeep $\mathrm{K}^{1^{*}}$, Atri $\mathrm{NS}^{2}$ and Munruchi $\mathrm{K}^{2}$ \\ ${ }^{1}$ Desh Bhagat College of Education, Bardwal-Dhuri-148024, Punjab, India. \\ ${ }^{2}$ Department of Botany, Punjabi University, Patiala-147002, Punjab, India.
}

Amandeep K, Atri NS, Munruchi K 2013 - Diversity of species of the genus Bolbitius (Bolbitiaceae, Agaricales) collected on dung from Punjab, India. Mycosphere 4(6), 1053-1064, Doi 10.5943/mycosphere/4/6/3

\begin{abstract}
This paper deals with the collections of Bolbitius made from various dung localities of Punjab. Presently, six coprophilous species of the genus, namely B. coprophilus, B. demangei, B. glatfelteri, B. marginatipes, B. titubans and B. vitellinus are reported from a variety of herbivorous dung types. A dichotomous key to aid in the identification of these taxa is given. The taxonomy of 05 taxa is described and illustrated with line drawings of morphological and anatomical features. Bolbitius demangei, B. glatfelteri and B. marginatipes are new records from India.
\end{abstract}

Key words - Agaricales - coprophilous - new records - taxonomy

\section{Introduction}

The genus Bolbitius Fr., belonging to the family Bolbitiaceae Sing., is characterized by fragile, usually brightly colored carpophores, viscid pileus surface, sulcate-plicate to pectinate pileal margin, free lamellae, non-capitate cheilocystidia and hymeniform pileus cuticle. Bolbitius species grow on a variety of substrates such as on dung, on humus, inside and outside the forested areas, on rotten trunks of trees, on swampy or sandy soil, sawdust, etc. (Singer 1986, Pegler 1986).

According to Kirk et al. (2008), 25 species of this genus are known so far the world over. Myco Bank (www.mycobank.org) shows 101 records of the genus up to 05 September, 2013. From India as many as 10 species, namely B. acer, B. aleuriatus, B. coprophilus, B. edulis, B. fissus, B. grandiusculus, B. mesosporus, B. tener, B. titubans and B. vitellinus have been documented (Bilgrami et al. 1991, Saini \& Atri 1995, Natarajan et al. 2005, Manimohan et al. 2007, Atri et al. 2009, Mohanan 2011). Out of these, B. coprophilus has been recorded growing on elephant dung from Kerala state (Thomas et al. 2001, Manimohan et al. 2007). From Punjab, B. vitellinus was recorded growing on horse dung (Rea 1922, Mahju 1933) and B. titubans on buffalo dung (Atri et al. 2009).

During the surveys conducted to various dung localities of Punjab in North-West India, eight coprophilous collections belonging to six species of Bolbitius, namely B. coprophilus, $B$. demangei, B. glatfelteri, B. marginatipes, B. titubans and B. vitellinus have been found. 


\section{Material \& Methods}

For collection, preservation and description of agarics, standard methodology and terminology was used (Singer 1986, Pegler 1977, 1986, Atri et al. 2005). The colour terminology used for macroscopic description is that of Kornerup \& Wanscher (1978). The specimens were hot air dried and preserved in cellophane bags containing 1-4 dichlorobenzene (Smith 1949, Atri \& Saini 2000). The hand cut sections of various parts of carpophore such as pileus, gills, stipe and basidiospore details were studied under the microscope and the drawings were made with the aid of camera lucida under an oil immersion lens. All the collections examined have been deposited in the Herbarium of Botany Department, Punjabi University, Patiala (Punjab), India under PUN.

\section{Key to the investigated coprophilous species of Bolbitius}

1 Both pileus and stipe surfaces white; clamp connections present in stipe context hyphae; basidiospores $14.4-16 \times 8.5-9.3(10) \mu \mathrm{m}$. B. glatfelteri

$\mathbf{1}^{\prime}$ Pileus not white; stipe white or colored; clamp connections absent..........................2

2 Pileus olive brown to some shade of grayish brown but never reddish..........................3

$\mathbf{2}^{\prime}$ Pileus reddish brown to brown but never with olive or grayish shade.........................5

3 Pileus elongated ellipsoidal, exumbonate; stipe surface white, unchanging on bruising, fibrillose near the base, longitudinally striate, with a bulbous base........................ marginatipes 3' Pileus may be convex, conical, campanulate to even applanate, umbonate; stipe creamish to pale yellow or even reddish white, unchanging or changing to some shade of brown on bruising,

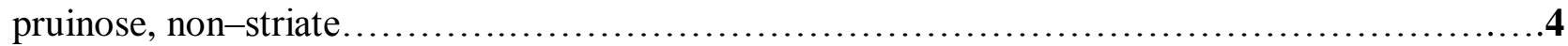
4 Pileus grayish brown with dark brown umbo having bright yellow shade, delicate, membranous, grooved; stipe creamish, unchanging on bruising, hollow, slightly swollen at both ends; lamellae crowded, narrow, up to $0.2 \mathrm{~cm}$ broad, rusty brown; basidia mostly $2-$ spored.

B. titubans

4' Pileus brownish yellow with thick brown umbo; stipe surface pale yellow, changing to yellowish brown on bruising, solid, equal; lamellae distant, broad, up to $0.5 \mathrm{~cm}$ broad, olive brown; basidia 2and 4-spored....

B. vitellinus

5 Carpophores $4.3-9.7 \mathrm{~cm}$ in height; lamellae yellowish brown to reddish brown at maturity, becoming grayish yellow on drying; stipe reddish white, bruising reddish then

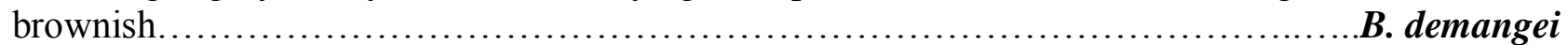

5' Carpophores 2.5-20.5 cm in height; lamellae white to pale yellow when young, grayish brown to brown at maturity; stipe pale yellow, unchanging.

B. coprophilus

\section{Taxonomic descriptions}

Bolbitius glatfelteri Peck in Bull. Torr. Bot. Cl. 30: 97, 1903.

Figs. 1-2

Synonym - Mycena glatfelteri (Peck) Murrill in N. Amer. Flora, 1917.

Carpophores $8.5-12 \mathrm{~cm}$ in height. Pileus $2.2-3.7 \mathrm{~cm}$ broad, applanate, umbonate; umbo broad, brownish beige $\left(6 \mathrm{D}_{3}\right)$; surface dry, atomate, smooth, white $\left(3 \mathrm{~A}_{1}\right)$; margin irregular, splitting at maturity, striated; cuticle not peeling; flesh thin, white, unchanging, non-deliquescent; pileal veil absent; taste and odor none. Lamellae free, equal, crowded, narrow, $0.2-0.25 \mathrm{~cm}$ broad, wavy, fragile, brownish orange $\left(5 \mathrm{C}_{6}\right)$. Stipe central, $8.3-11.9 \mathrm{~cm}$ long, $0.5-0.7 \mathrm{~cm}$ broad, cylindrical, slightly bulbous at the base, pruinose-fibrillose, hollow, surface white $\left(3 \mathrm{~A}_{1}\right)$, unchanging on bruising; annulus absent.

Basidiospores 14.4-16 × 8.5-9.3(10) $\mu \mathrm{m}(\mathrm{Q}=1.7)$, ellipsoidal, truncated with apical germ pore, thick-walled, smooth, brownish yellow with dark brown walls; apiculus central, $0.85 \mu \mathrm{m}$ long. Basidia 25.5-39 × 12-19.5 $\mu \mathrm{m}$, clavate, $2-$ and 4- spored, thin walled, slightly granular; sterigmata $2.5-4.3 \mu \mathrm{m}$ long. Gill edges sterile. Cheilocystidia $29-56 \times 8.5-22 \mu \mathrm{m}$, polymorphic, cylindrical, clavate, inflated clavate, ventricose fusoid or subglobose, thin-walled, hyaline to granular. Pleurocystidia absent. Pileus cuticle hymeniform, cellular elements $18.7-46 \times 8.5-15.3$ 

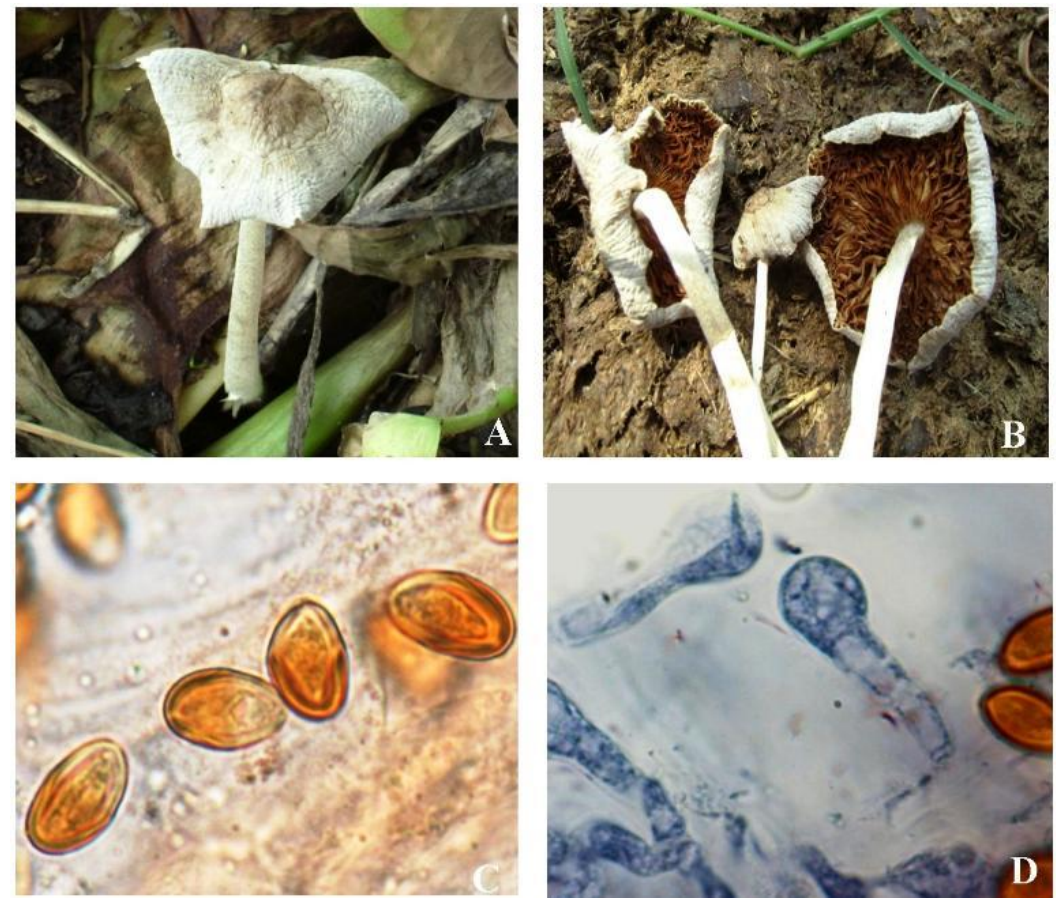

Fig. 1 - Bolbitius glatfelteri. A Carpophore growing in natural habitat. B Pileal undersurface showing crowded, wavy lamellae. C Basidiospores. D Pileal cuticle elements.

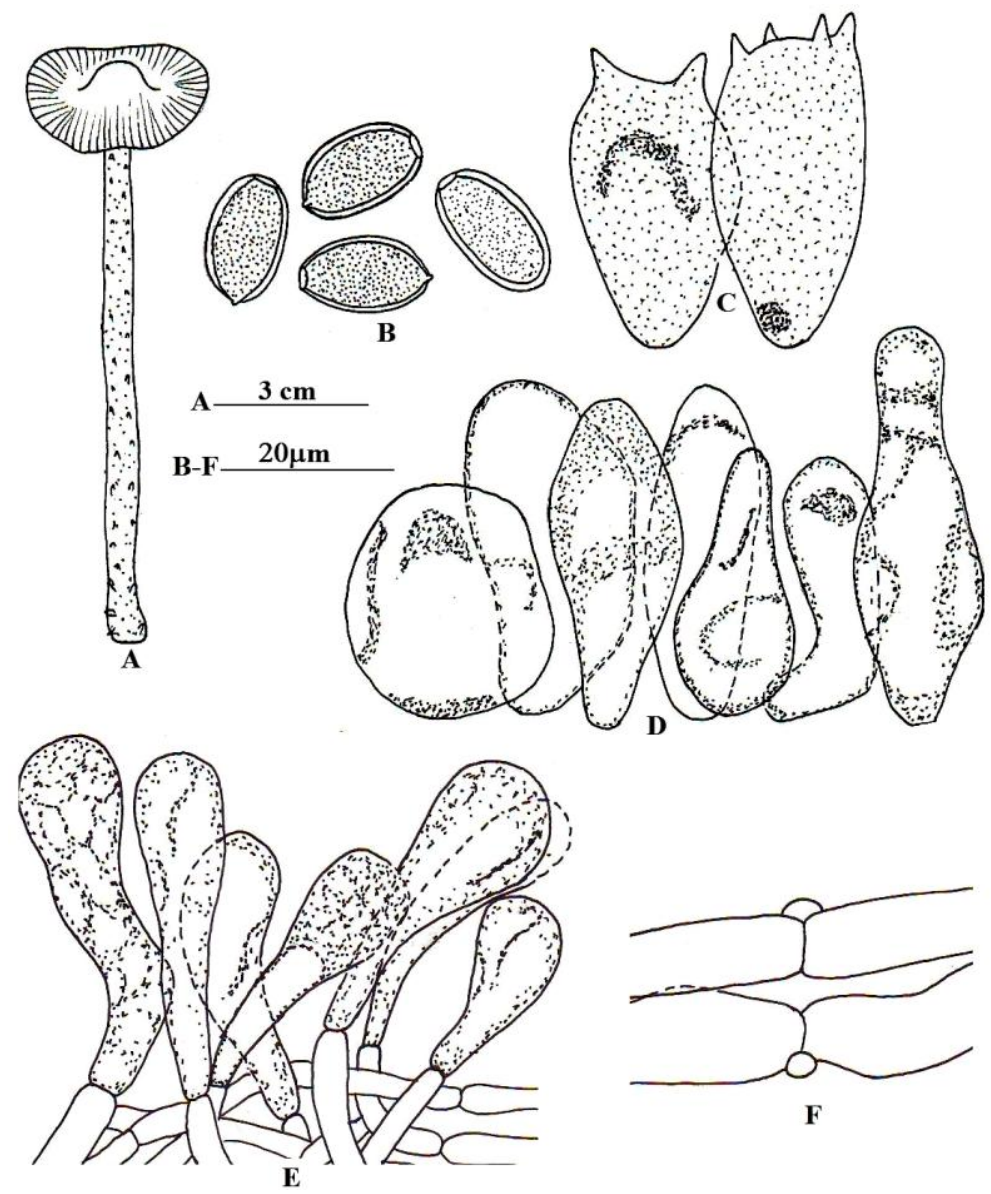

Fig. 2 - Bolbitius glatfelteri. A Carpophore. B Basidiospores. C Basidia. D Cheilocystidia. E Pileal elements. F Stipe context hyphae with clamps. 
$\mu \mathrm{m}$, cylindrical or clavate, thin walled, granular; pileus context homoiomerous, made up of thinwalled 3.4-6.8 $\mu \mathrm{m}$ broad hyaline hyphae. Stipe cuticle composed of longitudinally running, thinwalled, hyaline 6-12.7 $\mu \mathrm{m}$ broad hyphae. Clamp connections present in stipe context hyphae.

Material examined - India, Punjab, Patiala (251 m a.s.1.), Bhedpura, growing scattered in a group on buffalo dung mixed with leaf litter, 16 July 2011, Amandeep Kaur, PUN 4797.

Remarks - The above examined collection belongs to B. glatfelteri (Singer 1977). It is recognized by white colored pileus having yellowish or tawny umbo and white stipe. It is a new fungus record for India.

Saccardo (1905) documented this species to be growing gregariously or in caespitose groups on dung from North America while Murrill (1917) reported it growing on rotten manure from North America.

Bolbitius marginatipes Zeller in Mycologia 25 (5): 378, 1933.

Figs. 3-4

Carpophores $8.4-8.6 \mathrm{~cm}$ in height. Pileus $2.2-2.4 \mathrm{~cm}$ broad, $2-2.4 \mathrm{~cm}$ high, elongated ellipsoidal, exumbonate; surface viscid, smooth, delicate, grayish beige $\left(4 \mathrm{C}_{2}\right)$ towards the apex, brownish gray $\left(4 \mathrm{D}_{2}\right)$ towards the periphery; margin irregular, splitting at maturity, striate; apex rounded smooth; cuticle not peeling; flesh thin, yellowish white, unchanging, non-deliquescent; pileal veil absent; taste and odor none. Lamellae almost free, equal, crowded, narrow, up to $0.2 \mathrm{~cm}$ broad, smooth, fragile, grayish beige $\left(4 \mathrm{C}_{2}\right)$ in young carpophores, yellowish brown $\left(5 \mathrm{E}_{7}\right)$ at maturity. Spore print grayish brown $\left(6 \mathrm{D}_{3}\right)$. Stipe central, $8.3-8.5 \mathrm{~cm}$ long, $0.7-0.8 \mathrm{~cm}$ broad, cylindrical, equal with bulbous base, fibrillose near the base, longitudinally striated, hollow, surface white, delicate, unchanging on bruising; annulus absent.

Basidiospores 12-15 × 7-9 $\mu \mathrm{m}(\mathrm{Q}=1.68)$, ellipsoidal, truncated with a broad germ pore, thick-walled, smooth, yellowish brown. Basidia 18.7-32.3 × 10-12.7 $\mu \mathrm{m}$, clavate, 4- spored, thin walled, hyaline; sterigmata $2.5-3.4 \mu \mathrm{m}$ long. Gill edges sterile. Cheilocystidia 29-49.3 $\times 5-17 \mu \mathrm{m}$, cylindrical to lageniform, thin-walled, granular. Pleurocystidia absent. Pileus cuticle hymeniform, cellular elements $25.5-46 \times 5-13.6 \mu \mathrm{m}$, cylindrical, clavate or piriform, thin walled, granular; pileus trama homoiomerous, made up of interwoven, thin-walled, hyaline $1.7-12 \mu \mathrm{m}$ broad hyphae. Stipe cuticle with scattered caulocystidia measuring $20.4-57.8 \times 6.8-12 \mu \mathrm{m}$ in size, caulocystidia cylindrical to clavate, thin-walled, hyaline, some with granular tips; stipe context hyphae longitudinally parallel, cylindrical, thin-walled, hyaline, 3.4-15.3 $\mu \mathrm{m}$ broad. Clamp connections absent.

Material examined - India, Punjab, Sangrur (231 m a.s.1.), Haidernagar, growing scattered on buffalo dung, 29 June 2011, Amandeep Kaur, PUN 4798.

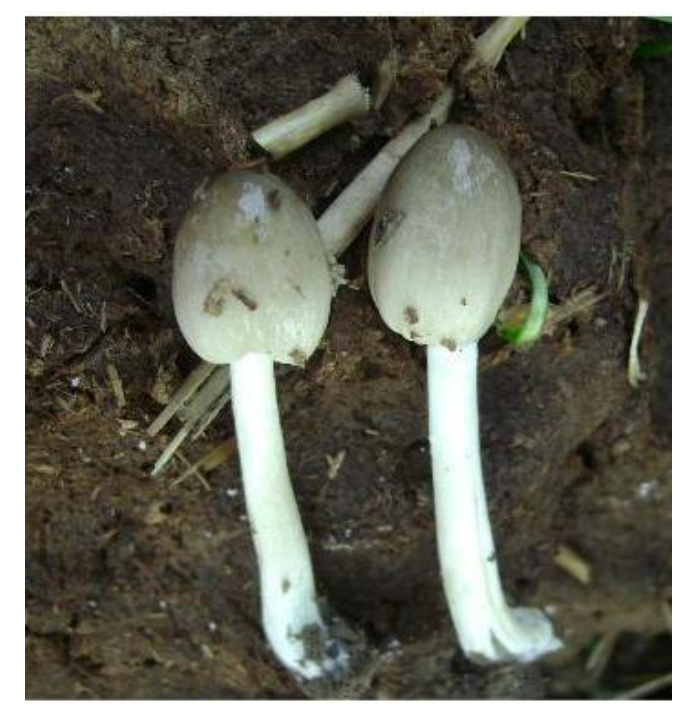

Fig. 3 - Bolbitius marginatipes. Carpophores growing in natural habitat. 


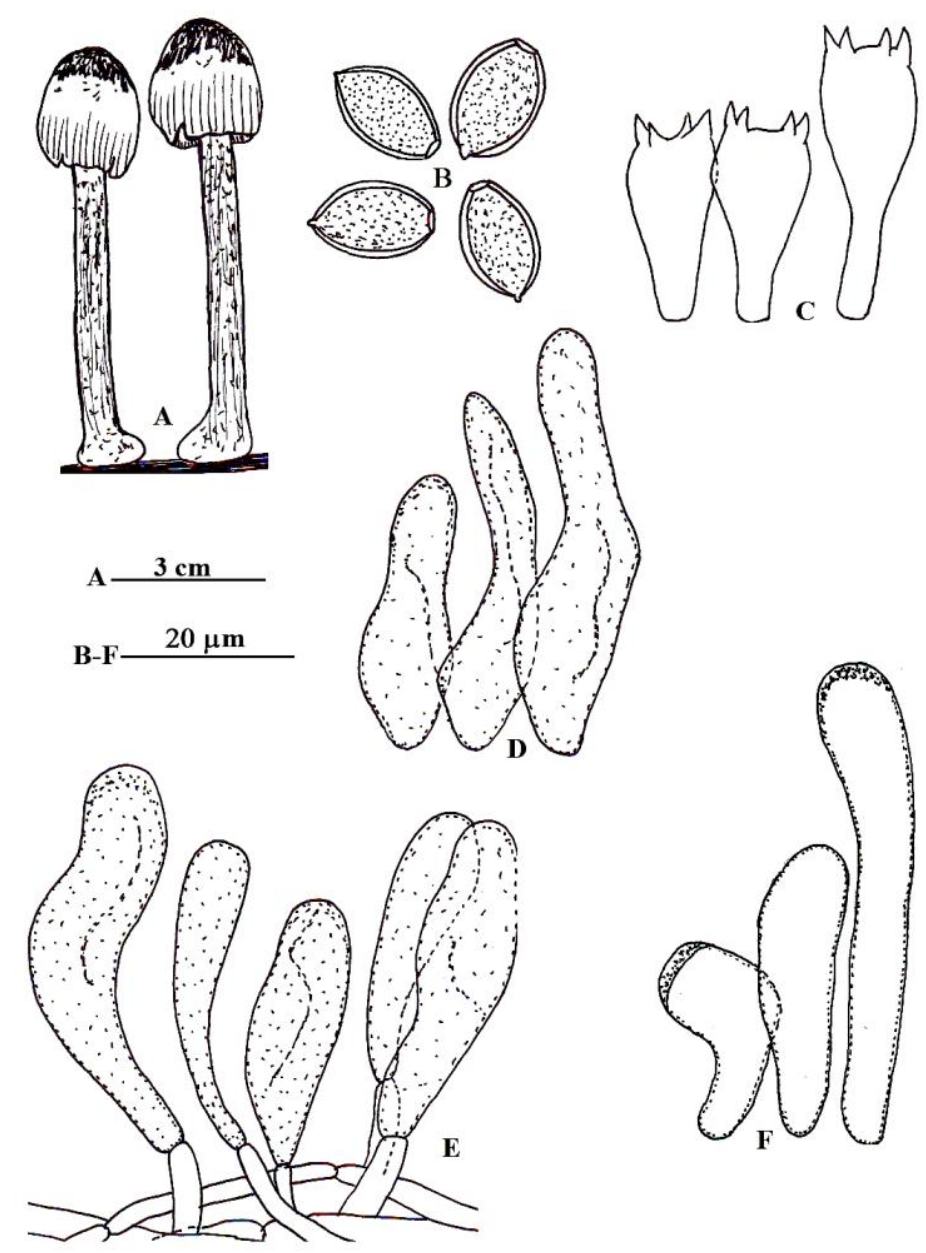

Fig. 4 - Bolbitius marginatipes. A Carpophores. B Basidiospores. C Basidia. D Cheilocystidia. E Pileal elements. F Caulocystidia.

Remarks - The morphological and anatomical details of this collection are in conformity with the description given for B. marginatipes by Zeller (1933) except for the attachment of gills which are almost free from the stipe in the present collection as compared to adnate described by Zeller (1933). The color of the pileus is typically grayish beige or Isabella towards the apex and the stipe is cylindrical from a marginate bulbous base which are typical diagnostic features of $B$. marginatipes. This species is being reported for the first time from India.

Bolbitius titubans (Bull.) Fr. in Epicrisis Systematis Mycologici p. 254, 1838.

Basionym - Agaricus titubans Bulliard in Herb. France 9: 425, 1789. 1821.

Synonyms - Prunulus titubans (Bull.) Gray in A Natural Arrangement of British Plants 1:

Pluteolus titubans (Bull.) Quél. in Flore Mycol. de France 83,1888.

Bolbitius vitellinus subsp. titubans (Bull.) Konrad \& Maubl. in Icones Selectae Fungorum Fasc. 4: 171, 1928.

Bolbitius vitellinus var. titubans (Bull.) M.M. Moser ex Bon in Doc. Mycol. 18 (70-71): 37, 1987.

Material examined - India, Punjab, Sangrur (251 m a.s.1.), Ratolan, growing solitary on buffalo dung, 29 September 2008, Amandeep Kaur, PUN 3896.

Remarks - B. titubans is characterized by its delicate and sticky carpophore and growth commonly on dung. It is also known as the 'Egg Yolk Fungus' as the young pileus is egg-shaped and chrome-yellow but it is reported to expand like a parasol and fade at maturity (Watling \& Taylor 1987). 
Taylor (1983) collected the specimens growing on mown grass-straw from New Zealand. Watling \& Taylor (1987) recorded the species again from New Zealand. Jordon (1995) described the species growing scattered or in small clusters on soil, in rich or manured grasslands and rotting manured straw during summer to autumn from Britain and Europe. Atri et al. (2009) described it from Punjab, India. Mohanan (2011) rerecorded this species from Kerala state in India.

Bolbitius vitellinus (Pers.) Fr. in Epicrisis Systematis Mycologici p. 254, 1838.

Basionym - Agaricus vitellinus Pers. in Synopsis Methodica Fungorum p. 402, 1801.

Synonyms - Pluteolus vitellinus (Pers.) Quél. in Flore Mycol. de France p. 83, 1888.

Cortinarius vitellinus (Fr.) Bigeard \& H. Guill. in La Flore des Champignons supérieur de France, 1: 255, 1909.

Bolbitius vitellinus subsp. fragilis (Fr.) Konr. \& Maubl. in Icon. Sel. Fung. 2: 171, 1930.

Bolbitius titubans var. vitellinus (Pers.) Courtec. in Doc. Mycol. 34(135-136): 49, 2008.

Carpophore $11.5 \mathrm{~cm}$ in height. Pileus $3.2 \mathrm{~cm}$ broad, $1.5 \mathrm{~cm}$ high, convex; umbonate, umbo broad, nippled, thick at the base, brown $\left(6 \mathrm{D}_{8}\right)$; surface dry, delicate, brownish yellow $\left(5 \mathrm{C}_{7}\right)$, glabrous; margin regular, pellucid striate; flesh thin, non-deliquescent; pileal veil absent; taste and odor not distinctive. Lamellae free, unequal, 4-sized, close, broad, up to $0.5 \mathrm{~cm}$ broad, olive brown $\left(4 \mathrm{D}_{7}\right)$, fragile; gill edges wavy near the margin. Stipe central, $11.4 \mathrm{~cm}$ long, $0.4 \mathrm{~cm}$ broad, cylindrical, equal, solid, surface pale yellow $\left(4 \mathrm{~A}_{3}\right)$, changing to yellowish brown $\left(5 \mathrm{D}_{8}\right)$ on bruising, pruinose, delicate; annulus absent.

Basidiospores 10-13 ×6-8 $\mathrm{m}(\mathrm{Q}=1.64)$, elongated ellipsoidal, truncated by a central germ pore, thick-walled, smooth, yellowish brown. Basidia 14-18.5 × 7.8-10 $\mu \mathrm{m}$, clavate, $2-$ and 4- spored; sterigmata 2-2.8 $\mu \mathrm{m}$ long. Gill edges sterile. Cheilocystidia 23-27 $\times 8.5-11.5 \mu \mathrm{m}$, clavate to sphaeropedunculate, thin-walled, hyaline to granular near the tips. Pleurocystidia absent. Pileus cuticle hymeniform, cellular elements arranged parallel to one another, 24-30 × 7-13 $\mu \mathrm{m}$, inflated, piriform, clavate to spheropedunculate, thin walled, hyaline; pileus trama homoiomerous, made up of interwoven thin walled 3-10 $\mu \mathrm{m}$ broad hyphae. Hymenophoral trama subregular, composed of thin-walled narrow 4.4-11.4 $\mu \mathrm{m}$ broad hyphae. Subhymenium pseudoparenchymatous. Stipe cuticle with scattered caulocystidia measuring $20-31 \times 5.7-7 \mu \mathrm{m}$ in size, caulocystidia clavate to lageniform, thin-walled, hyaline, without any septa, some with granular apices; stipe context made up of cylindrical, longitudinally tangled, thin-walled 7-21 $\mu \mathrm{m}$ broad hyphae. Clamp connections absent throughout.

Material examined - India, Punjab, Sangrur (231 m a.s.1.), Alipur, growing solitary on buffalo dung heap, 08 June 2008, Amandeep Kaur, PUN 4214.

Remarks - The macroscopic and microscopic details of the above examined collection are in conformity with the key features and taxonomic details of B. vitellinus as given by Singer (1977), Pegler (1977) and Watling (1982). In many of its features it comes quite close to $B$. coprophilus and $B$. variicolor. From the former it differs in lacking pink tinge in the pileus and from the later in lacking olivaceous hues (Watling 1982).

B. vitellinus is a common coprophilous species which is reported to have world-wide distribution. Pegler (1977) recorded the species growing among grasses grazed by sheep during the months of March and June from Kenya and growing on elephant dung in the month of May from Tanzania. From India the species has already been recorded growing on horse dung from Punjab by Rea (1922) and Mahju (1933).

Bolbitius demangei (Quél.) Sacc. \& D. Sacc. in Sylloge Fungorum 17: 74, 1905.

Figs. 6-7

Basionym - Pluteolus demangei Quél. in Compt. Rend. Assoc. Franç. Avancem. Sci. 3: 495, 1902.

Carpophores $4.3-9.7 \mathrm{~cm}$ in height. Pileus $1.9-5.3 \mathrm{~cm}$ broad, $1.5-3.4 \mathrm{~cm}$ high, campanulate; umbonate, umbo short, reddish brown $\left(9 \mathrm{E}_{4}\right)$ to brown $\left(6 \mathrm{E}_{7}\right)$; surface viscid, delicate, brownish red $\left(10 \mathrm{C}_{8}\right)$ to reddish orange $\left(7 \mathrm{~A}_{6}\right)$ towards the apex, yellowish white $\left(4 \mathrm{~A}_{2}\right)$ towards margin, 


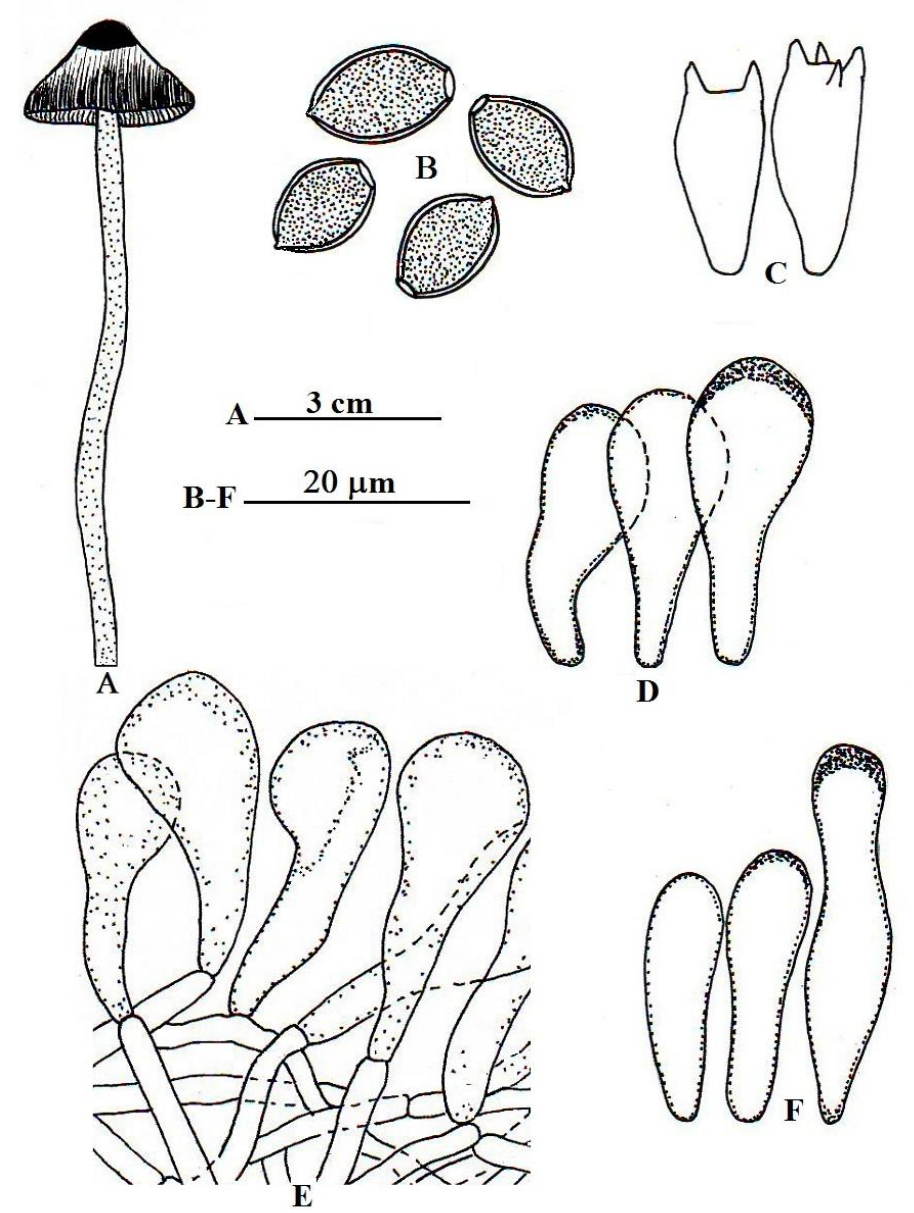

Fig. 5 - Bolbitius vitellinus. A Carpophore. B Basidiospores. C Basidia. D Cheilocystidia. E Pileus cuticle elements. F Caulocystidia.

hygrophanous, fades to yellowish brown (5E8) on drying; pileal veil scaly, scales appressed fibrillose, more aggregated along the apex; margin regular, splitting at maturity, striated; cuticle not peeling; flesh thin, yellowish white, becoming brown when bruised, non-deliquescent; taste and odor none. Lamellae adnexed to free, unequal, crowded, narrow to moderately broad, $0.15-0.4 \mathrm{~cm}$ broad, smooth, fragile, yellowish brown $\left(5 \mathrm{E}_{5}\right)$ to reddish brown $\left(8 \mathrm{D}_{7}\right)$, becoming grayish yellow $\left(2 \mathrm{~B}_{7}\right)$ on drying. Spore print reddish brown $\left(8 \mathrm{D}_{7}\right)$. Stipe central, $4.2-9.5 \mathrm{~cm}$ long, $0.4-0.9 \mathrm{~cm}$ broad, cylindrical, equal to slightly swollen at the base, fibrillose, hollow, surface reddish white $\left(10 \mathrm{~A}_{2}\right)$, changing to reddish then brownish on handling, delicate; annulus absent.

Basidiospores $12-15.3 \times 7.6-9.3 \mu \mathrm{m}(\mathrm{Q}=1.61)$, ellipsoidal, truncated with a germ pore, thick-walled, smooth, brownish yellow. Basidia 17-39 × 10-16 $\mu \mathrm{m}$, clavate, 2- and 4- spored, thin walled, with granulose contents in the upper part; sterigmata $2.5-3.4 \mu \mathrm{m}$ long. Gill edges sterile. Cheilocystidia abundant, $15.3-51 \times 7.6-40 \mu \mathrm{m}$, polymorphic, cylindrical, clavate, inflated clavate, lageniform to ventricose fusoid, sometimes with forking tips, thin-walled, granular, densely granular at the apices. Pleurocystidia absent. Pileus cuticle hymeniform, cellular elements 18.7-60 $\times 5-15.3 \mu \mathrm{m}$, cylindrical to clavate, sometimes forking, parallel to each other, thin walled, granular, sometimes pseudoseptate; pileus trama homoiomerous, made up of interwoven, thin-walled, hyaline 3.4-20.4 $\mu \mathrm{m}$ broad hyphae. Hymenophoral trama hyphae parallel, thin walled, narrow, 3.4$10 \mu \mathrm{m}$ broad. Stipe cuticle with abundant caulocystidia measuring 20.4-42.5 $\times$ 8.5-16 $\mu \mathrm{m}$, cylindrical to clavate, thin-walled, granular; stipe context composed of longitudinally parallel, cylindrical, thin-walled, hyaline 5-18.7 $\mu \mathrm{m}$ broad hyphae. Clamp connections absent. 

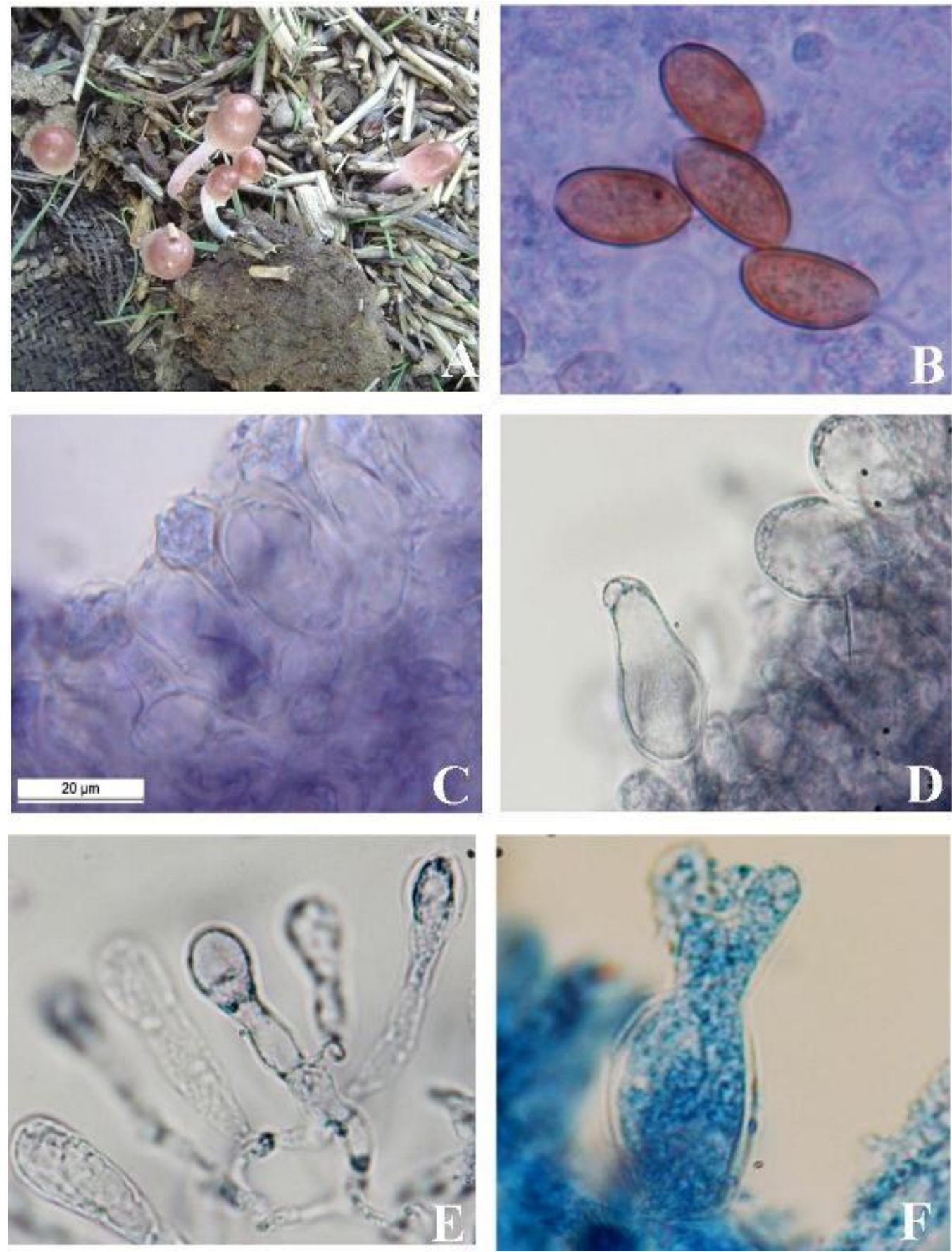

Fig. 6 - Bolbitius demangei. A Carpophores growing in natural habitat. B Basidiospores. C Pseudoparaphyses present between the basidia. D Lamella edge showing cheilocystidia. E Pileal elements. F Caulocystidium.

Materials examined - India, Punjab, Sangrur (231 m a.s.1.), Binzoki, growing in groups on buffalo dung and rotting Jute fabric, 29 June 2011, Amandeep Kaur, PUN 4795; Faridkot (196 m a.s.l.), Chandwaja, growing in a group on mixture of cattle dung and straw, 19 August 2011, Amandeep Kaur, PUN 4796.

Remarks - The above examined collections are typical of B. demangei (Singer 1977). The diagnostic characters of these collections are in agreement with the details given by Hausknecht and Contu (2006) for this species. It is a new fungus record for India. 


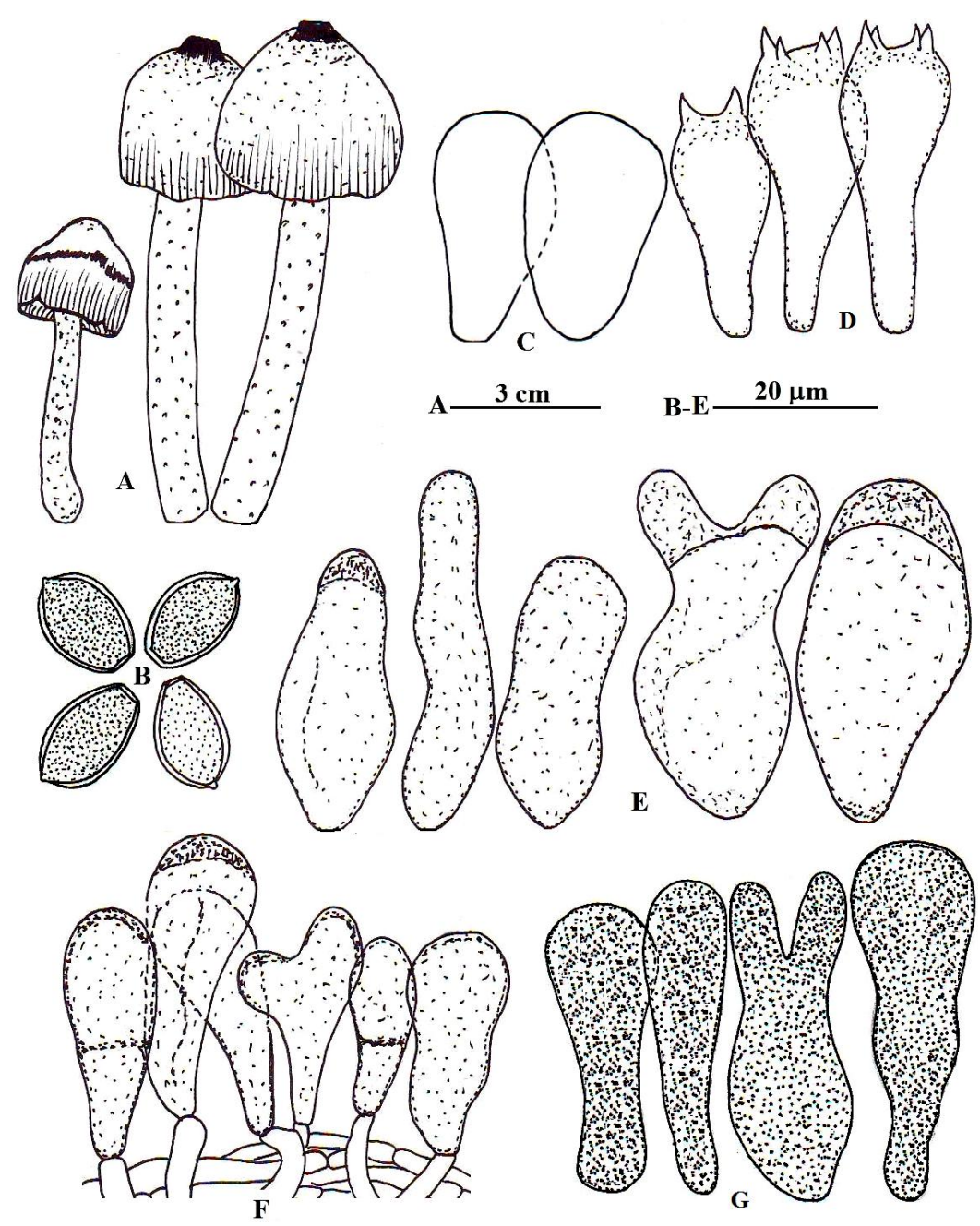

Fig. 7 - Bolbitius demangei. A Carpophores. B Basidiospores. C Pseudoparaphyses. D Basidia. E Cheilocystidia. F Pileal elements. G Caulocystidia.

The specimens of this species are reported to grow on the mixture of fertilizer and earth from France (Quélet 1902). Singer \& Digilio (1953) documented it growing in a garden on dung from Argentina. This species is reported to be distributed in Europe, North and South America and Asia growing on dung, on rotting vegetable matter, fabrics, etc. or on earth in open grassy places by Singer (1977) while Arnolds (2005) reported the species in Cucumber greenhouse on substrate rich in straw from the Netherlands. Hausknecht \& Contu (2006) collected it growing in a grassy to sandy place on plant rubbish and from dung as well as a mixture of straw and fertilizer from Italy. Maruyama (2011) reported it on the weeds, garbage and cow manure from Japan during autumn and summer seasons. Present collections have been made from coprophilous habitats of Punjab in India during mid August.

Bolbitius coprophilus (Peck) Hongo in Mem. Fac. Lib. Arts Educ., Shiga University, Nat. Sci. 9: 82, 1959.

Figs. 8-9 139, 1894.

Basionym - Pluteolus coprophilus Peck in Annual Rep. New York St. Mus. Nat. Hist. 4:

Synonym - Bolbitius radians Morgan J. Cincinnati Soc. Nat. Hist. 18: 36, 1895.

Carpophores $2.5-20.5 \mathrm{~cm}$ in height. Pileus 2.3-7 cm broad, 2-4.2 $\mathrm{cm}$ high, campanulate when young, conical at maturity, finally applanate; umbonate, umbo broad, nippled, reddish brown $\left(9 \mathrm{D}_{5}\right)$ to brown $\left(6 \mathrm{E}_{7}\right)$; surface viscid, smooth, delicate, pinkish $\left(9 \mathrm{~A}_{2}\right)$ to reddish brown $\left(8 \mathrm{D}_{5}\right)$ when young, yellowish brown $\left(5 \mathrm{E}_{7}\right)$ at maturity; margin irregular, pellucid, striate, radially splitting at maturity; flesh thin, pale, unchanging, non-deliquescent, withering; pileal veil absent; taste and 
odor not distinctive. Lamellae free, unequal, crowded, narrow to moderately broad, $0.2-0.35 \mathrm{~cm}$ broad, white $\left(9 \mathrm{~A}_{2}\right)$ to pale yellow $\left(4 \mathrm{~A}_{3}\right)$ when young, grayish brown $\left(9 \mathrm{E}_{5}\right)$ to brown $\left(6 \mathrm{E}_{7}\right)$ at maturity, fragile; gill edges wavy and curled at maturity. Spore print reddish brown $\left(8 \mathrm{E}_{4}\right)$. Stipe central, 2.4-20.4 cm long, 0.4-0.7 cm broad, tubular, with slightly swollen base, hollow, surface pale yellow $\left(4 \mathrm{~A}_{3}\right)$, unchanging, pruinose-fibrillose, delicate, shiny, silky, some carpophores with white basal mycelium; annulus absent.

Basidiospores 10-15.3 × 6-9.3 $\mu \mathrm{m}(\mathrm{Q}=1.65)$, ellipsoidal, truncated by a broad germ pore, thick-walled, smooth, yellowish brown. Basidia 14-34 × 7-13.6 $\mu \mathrm{m}$, clavate to cylindrico-clavate, 4- spored, very rarely 2-spored; sterigmata thick, measuring 2-4.3 $\mu \mathrm{m}$ long. Gill edges sterile. Cheilocystidia 22.5-39 × 7-20 $\mu \mathrm{m}$, polymorphic, cylindrical, clavate-vesiculose, ventricose fusoid to lageniform-capitate, thin-walled, hyaline to granular along the walls. Pleurocystidia absent. Pileus cuticle hymeniform, made up of $17-51 \times 7-13.6 \mu \mathrm{m}$, inflated, piriform, clavate to sphaeropedunculate, thin walled, hyaline elements; pileus trama homoiomerous, made up of interwoven 2-14 $\mu \mathrm{m}$ broad hyphae. Hymenophoral trama regular composed of thin-walled, narrow, 2.8-15.3 $\mu \mathrm{m}$ broad hyphae. Subhymenium pseudoparenchymatous. Stipe cuticle having caulocystidia scattered on the surface; caulocystidia 22-37.4 $\times 6.0-12.7 \mu \mathrm{m}$, cylindrical, lageniform or clavate, thin-walled, hyaline; stipe context hyphae cylindrical, longitudinally tangled, thin-walled, hyaline, 5.7-34 $\mu \mathrm{m}$ broad. Clamp connections absent.

Materials examined - India, Punjab, Sangrur (231 m a.s.1.), Bamaal, growing gregariously on buffalo dung flakes near village pond, 22 July 2009, Amandeep Kaur, PUN 4793; Haidernagar, growing scattered on buffalo dung, 29 June 2011, Amandeep Kaur, PUN 4794.

Remarks - The macroscopic and microscopic detail of the above examined collections fall within the overall taxonomic limits of B. coprophilus (Singer 1977, Watling 1982, Hausknecht \& Krisai-Greilhuber 2003). This species is characterized by its flesh-colored pastel pink pileus when young which darkens to pale brown to pale gray brown at maturity and absence of bright yellow colors on pileus and stipe (Hausknecht \& Krisai-Greilhuber 2003).

The species has been reported growing on horse manure from Austria (Hausknecht \& Krisai-Greilhuber 2003). As compared Watling (1982) documented it growing on wheat-chaff and straw stacked in yards from England and Netherlands. From India, Atri et al. (1992) reported it growing in open areas among grasses from Punjab while Thomas et al. (2001) and Manimohan et al. (2007) reported it growing on elephant dung from Kerala.
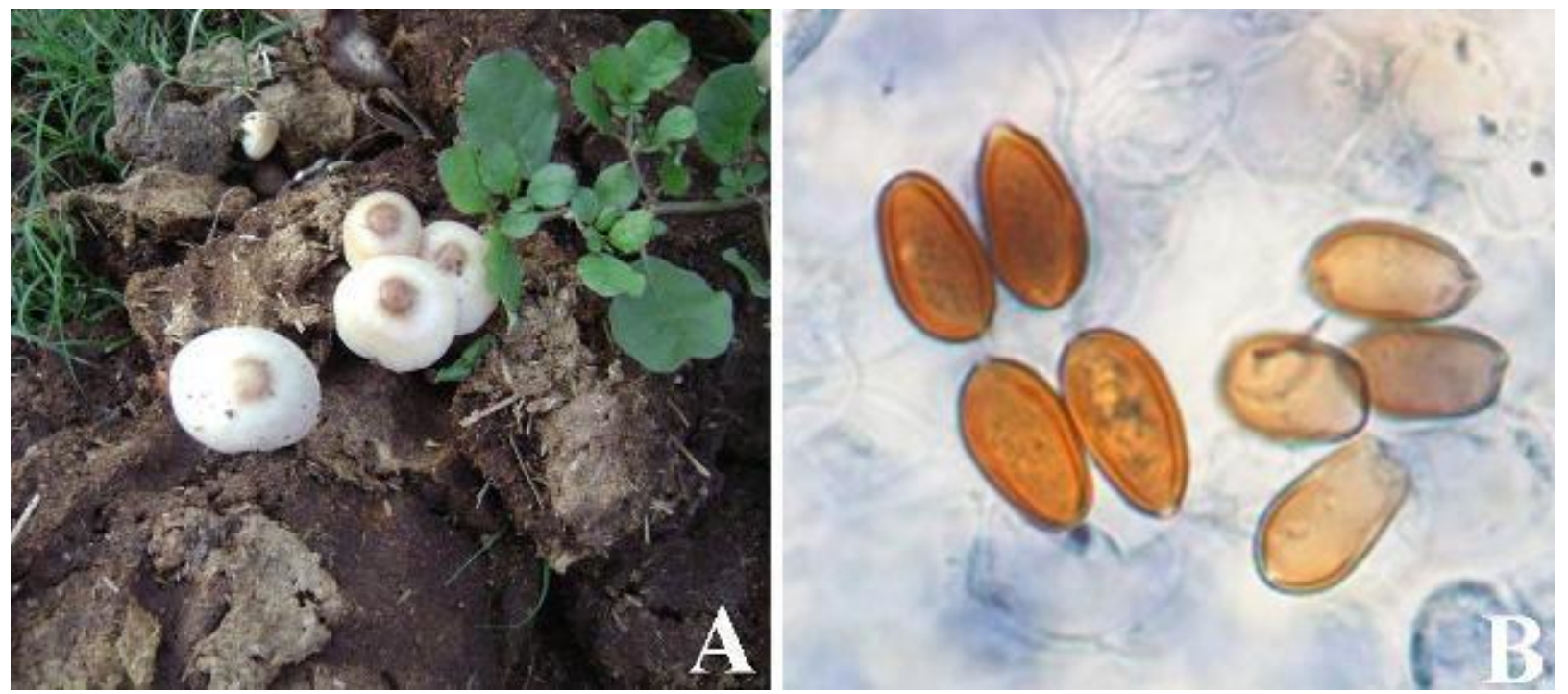

Fig. 8 - Bolbitius coprophilous. A Carpophores in their natural habitat. B Basidiospores. 

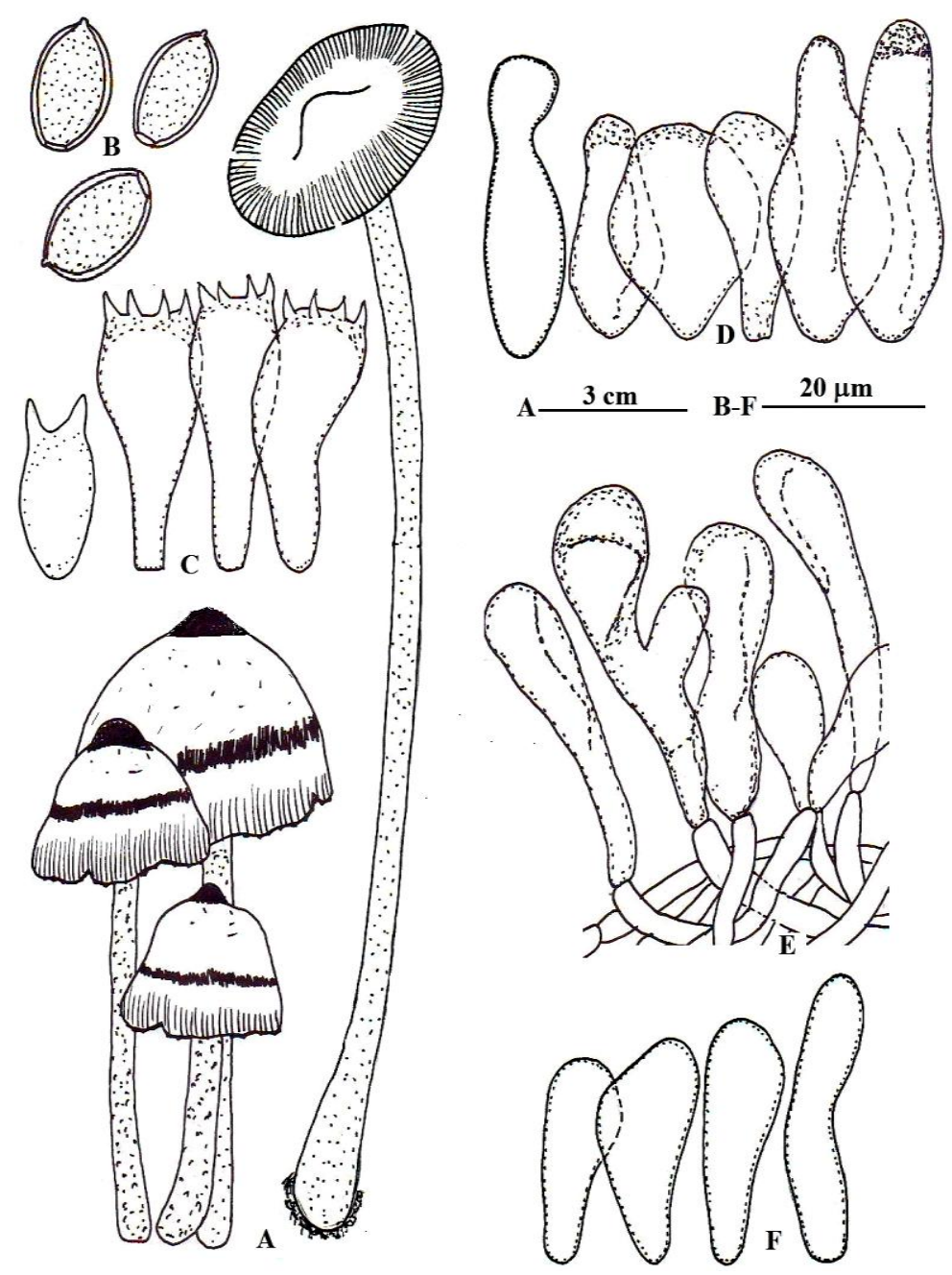

Fig. 9 - Bolbitius coprophilus. A Carpophores. B Basidiospores. C Basidia. D Cheilocystidia. E Pileal elements. F Caulocystidia.

\section{Acknowledgements}

Authors wish to thank Department of Botany, Punjabi University, Patiala, Punjab for providing laboratory facilities and acknowledge the grant-in-aid for financial assistance under SAP-III programme of D.R.S. by University Grants Commission, New Delhi.

\section{References}

Arnolds E 2005 - Bolbitiaceae. In: Flora Agaricina Neerlandica 6, Coprinaceae and Bolbitiaceae (eds ME Noordeloos, TW Kuyper, Vellinga EC). Boca Raton, London, New York, Singapore, Taylor \& Francis.

Atri NS, Kaur A, Kaur M. 2009 - Three new records of coprophilous mushrooms of family Bolbitiaceae from India. Mushroom Research 18 (2), 51-56.

Atri NS, Kaur A, Kour H. 2005 - Wild mushrooms-collection and identification. In: Frontiers in Mushroom Biotechnology (eds RD Rai, RC Upadhyay, SR Sharma). NRCM Solan, Himachal Pradesh, India, pp 9-26.

Atri NS, Saini SS. 2000 - Collection and study of Agarics- An introduction. Indian Journal of Mushrooms 18(1\&2), 1-5.

Atri NS, Saini SS, Kaur G. 1992 - Taxonomic studies on some members of family Bolbitiaceae Sing. from Punjab. Journal of the Indian Botanical Society 71(1\&2), 87-89.

Bilgrami KS, Jamalludin S, Rizwi AM. 1991 - Fungi of India. List and References. Today and Tomorrow's Printers and Publishers, New Delhi, India, pp 798. 
Hausknecht A, Contu M. 2006 - Bolbitius demangei in Italien. Österreichische Zeitschrift für Pilzkunde 15, 7-10.

Hausknecht A, Krisai-Greilhuber I. 2003 - Pilzbeobachtungen in einem neu geschaffenen Weidegebiet. Österreichische Zeitschrift für Pilzkunde 12, 101-123.

Jordon M 1995 - The Encyclopedia of Fungi of Britain and Europe. David and Charles Book Company Devon, pp 249.

Kirk PF, Cannon PF, Minter DW, Stalpers JA. 2008 - Ainsworth and Bisby's Dictionary of Fungi, 10th ed, CABI Bioscience, CAB International, UK.

Kornerup A, Wanscher JH. 1978 - Methuen Handbook of Colour, 3rd ed, Eyre Methuen, London.

Mahju NA 1933 - A Contribution to our knowledge of Indian coprophilous fungi. Journal of the Indian Botanical Society 12, 153-164.

Manimohan PK, Thomas A, Nisha VS. 2007 - Agarics on elephant dung in Kerala State, India. Mycotaxon 99, 147-157.

Maruyama K 2011 - Bolbitius demangei. Retrieved from the website http://www.ne.jp/asahi/mushroom/tokyo/Bolbitiaceae.html

Mohanan C 2011 - Macrofungi of Kerala. KFRI Handbook No. 27, Kerala Forest Research Institute, Peechi, Kerala, India.

Murrill WA 1917 - North American Flora, Vol 10, Parts 1-4, New York.

Natarajan K, Kumaresan V, Narayanan K. 2005 - A checklist of Indian Agarics and Boletes (19842002). Kavaka 33, 61-128

Pegler DN 1977 - A Preliminary Agaric flora of East Africa. Kew Bulletin Additional Series 6, London. pp 615.

Pegler DN 1986 - Agaric flora of Sri Lanka. Kew Bulletin Additional Series 12, London. pp 514.

Quélet L 1902- Quelques especes critiques ou nouvelles de la Flore Mycologique de France. Compte Rendu de la Association Française pour l'Avancement des Sciences 22, Ajaccio.

Rea C 1922 - British Basidiomycetaceae. A Handbook to the Larger British Fungi. Cambridge University Press, Cambridge, England. pp 799.

Saccardo PA 1905 - Sylloge Fungorum17. Supplementum Universale. Pars VI, Padova. pp 991.

Saini SS, Atri NS. 1995 - Mushroom flora of Punjab. In: Advances in Horticulture Vol 13Mushrooms (eds KL Chadha, SR Sharma). Malhotra Publishing House, New Delhi, India, pp 375-386.

Singer R 1977 - Keys for the identification of the species of Agaricales I. Sydowia Vol XXX, Heft $1-6$.

Singer R 1986 - The Agaricales in Modern Taxonomy, 4th ed, Sven Koeiltz Scientific Books, Germany. pp 981.

Singer R, Digilio APL. 1953 - Pródromo de la Flora Agaricina Argentina. Lilloa 25, 1-832.

Smith AH 1949 - Mushrooms in their Natural Habitats, Hafner Press, New York. pp 626.

Taylor GM 1983 - Some Common Fungi of Auckland City. Tane 29, 133-141.

Thomas KA, Hausknecht A, Manimohan P. 2001 - Bolbitiaceae of Kerala State, India: New species and new and noteworthy records. Österreichische Zeitschrift für Pilzkunde 10, 87114.

Watling R 1982 - British Fungus Flora- Agaric and Boleti 3. Bolbitiaceae: Agrocybe, Bolbitius, Conocybe, Edinburgh, HMSO, UK.

Watling R, Taylor GM. 1987 - Observations on the Bolbitiaceae. Bibliotheca Mycologia, 27 J Cramer, Berlin, Stuttgart.

Zeller SM 1933 - New or Noteworthy Agarics from Oregon. Mycologia 25(5), 376-391. 